\title{
Anti-inflammatory, antinociceptive and antidiarrhoeal activities of methanol and ethyl acetate extract of Hemigraphis alternata leaves in mice
}

S. M. Mushiur Rahman ${ }^{1 *}$, Md. Atikullah¹, Md. Nahinul Islam, Md. Mohaimenul', Foysal Ahammad², Md. Shaharul Islam¹, Bisti Saha ${ }^{1}$ and Md. Habibur Rahman ${ }^{1}$

\begin{abstract}
Background: The study was designed to investigate the qualitative phytochemical constituents and evaluate the anti-inflammatory, anti-nociceptive and anti-diarrhoeal activities of methanol (MHAL) and ethyl acetate (EAHAL) extract of Hemigraphis alternata leaves in Swiss albino mice.

Methods: Qualitative phytochemical constituents of MHAL and EAHAL were determined by different tests such as Molisch's test, Fehling test, Mayer's test, Frothing test, $\mathrm{FeCl}_{3}$ test, Alkali test, Salkowski's test, Keller-killiani test and $\mathrm{CuSO}_{4}$ test. In addition, Xylene induced-ear edema test and Cotton pellet-induced granuloma formation test had been performed to evaluate the anti-inflammatory activity. Moreover, Formalin-induced paw licking test, Acetic acid-induced writhing tests and Castor oil induced antidiarrheal test had been performed to evaluate the antinociceptive and anti-diarrhoeal activities respectively.

Results: These crude extracts were figured the presence of carbohydrates, flavonoids, tannins, glycosides, triterpenoids, fat and fixed oils. No mortality, behavioral changes or sign of any toxicity were observed up to the dose as high as $4000 \mathrm{mg} / \mathrm{kg}$ in mice. During anti-inflammatory test, MHAL $400 \mathrm{mg} / \mathrm{kg}$ and EAHAL $200 \mathrm{mg} / \mathrm{kg} \& 400$ $\mathrm{mg} / \mathrm{kg}$ were significantly reduced ear weight differences and granuloma formation in mice. Highest percentage inhibition was offered by EAHAL $400 \mathrm{mg} / \mathrm{kg}$ dose $(35.15 \pm 11.78 \%$ and $34.76 \pm 11.30 \%)$ in both anti-inflammatory tests respectively. In anti-nociceptive experiments, all extracts were significantly reduced paw licking and abdominal writhing of mice. Highest percentage inhibition was offered by EAHAL $400 \mathrm{mg} / \mathrm{kg}$ dose $(88.21 \pm 2.23 \%$ and $54.00 \pm$ 2.38\%) in both anti-nociceptive tests respectively. In addition, both extracts were showed significant inhibition of percentage of diarrhea in anti-diarrhoeal models except EAHAL $200 \mathrm{mg} / \mathrm{kg}$ dose and the apex percentage inhibition is offered by MHAL $400 \mathrm{mg} / \mathrm{kg}$ dose (67.73 $\pm 5.77 \%)$.
\end{abstract}

Conclusion: These results confirm that the leaves extract of Hemigraphis alternata are nontoxic and may provide a source of plant compounds with anti-inflammatory, anti-nociceptive and anti-diarrhoeal activities.

Keywords: Hemigraphis alternate leaves, Phytochemical screening, Anti-inflammatory, Anti-nociceptive, Antidiarrhoeal, Cotton pellet, Acetic acid-induced writhing

\footnotetext{
*Correspondence: smushiurjustphar@gmail.com

'Department of Pharmacy, Faculty of Biological Science and Technology, Jashore University of Science and Technology, Jashore 7408, Bangladesh Full list of author information is available at the end of the article
} 


\section{Background}

As a reliable source of remedies, thousands of medicinal plants are widely used as alternative medicines for the treatment or prevention of many life-threatening diseases [1]. Traditional, empirical and molecular approaches have been utilized to discover new medicines. The traditional approach provides drugs that have been found by trial and error over many years in different cultures and systems of medicine. Plant extracts contain various phytochemical components that identified as bioactive compounds and may be responsible for the diverse activities when herbs are used medicinally [2].

The plant Hemigraphis alternata belongs to Acanthaceae family is a versatile tropical low creeping Perennial herb that reaches a height of 15 to $30 \mathrm{~cm}$, which is the native of tropical Malaysia. It is also known as Purple Waffle plant, Aluminium plant, Cemetary plant, Metal leaf, Red flame Ivy, Java Ivy etc. [3]. This exotic plant was adapted to Bangladesh as well as India. The notable phytoconstituents that present in Hemigraphis alternata are carbohydrates, alkaloids, phenols, saponins, flavonoids, terpenoids, coumarins, carboxylic acid, xanthoproteins, tannins, proteins, steroids, chlorogenate, cinnamic acids, cinnamate and sterol [3-5]. This plant possesses various medicinal properties. The whole plant or leaves are used to treat the fresh wound, cuts, ulcers, inflammation and in folk medicines [6]. Traditionally the leaves are consumed to mend gallstone, excessive menstruation and as a contraceptive. It is used internally to cure anemia [3] gallstone, diuretic, haemorrhoids, and diabetes mellitus $[7,8]$.

Inflammation is the fountainhead of any symptoms of diseases in the body. Pharmacologically, inflammation is a complex biological response of vascular tissues against aggressive agents such as pathogens, irritants or damaged cells. Understanding inflammation has always been a conundrum for mankind. It can be initiated by many different stimulating factors, including physical damage, precursor chemicals, microbial invasion and immune responses [9]. The standard signs of inflammation are manifested by increased blood flow, elevated cellular metabolism, vasodilation, the release of soluble mediators, extravasations of fluids and cellular influx [10], excessive degeneration, exudation, necrosis, or the formation of abnormal granulation formation, that result in different degrees of injury to the body [11]. Due to the presence of the inflammatory agent, cell membranes induced the activation of phospholipase $\mathrm{A}_{2}$ followed by the release of arachidonic acid and inflammatory mediators such as- cytokines, serotonin, histamine, prostaglandin and leukotrienes that increase vascular permeability, thus facilitating the migration of leukotrienes the site of inflammation [12], and lead to a wide range of changes in pathology.

Nociception is an uncomfortable sensation that alerts the organism of a harmful situation to avoid major injuries.
It is a symptom of many diseases and it is calculated that about $80-100 \%$ of the population experience back pain at least once in the lifetime [1]. More than half of the patients suffering pain receive inadequate therapeutic management which severely affects their quality of life [13].

Steroidal and nonsteroidal anti-inflammatory analgesics are used to manage pain and inflammation. Moreover, reducing the inflammatory response is an effective way of decreasing the pain process [14]. Though these agents are beneficial, various adverse effects are experienced in long-term use of steroidal and nonsteroidal anti-inflammatory agents (NSAIDs). Liver damage, gastric lesions, initiation of cardiovascular problems and renal failure, fluid retention, bronchospasm and prolongation of bleeding time are experienced in NSAIDs drugs [1, 15-17]. On the other hand, erectile dysfunction, hypertension, manic depression, cramps, and dizziness are triggered by steroids as well as suppress the immune system [18]. Moreover, the social abuse besides dependency, addiction, tolerance, constipation, and respiratory problems are elicited by opioid analgesics [19].

Moreover, there is a growing interest in the search for alternative medicinal plants that, because of their chemical composition, have a better ability to mitigate these mediators of their multiple mechanisms to treat symptoms related to painful inflammatory process more effectively [14].

In developing countries, diarrheal disease is a very common ailment and national problem in many tropical countries and the leading cause of mortality and morbidity, especially among children resulting in a major healthcare problem $[20,21]$, accounts for more than 5-8 million deaths in newborn babies and children under 5 years of age, each year [22]. Medicinal plants play a key role in the development and advancement of modern studies on anti-diarrheal activities of substances. The search for more effective and safe agents from plant origin has continued to be a considerable area of active research. Hence, the World Health Organization encouraged studies for the treatment and prevention of diarrhoeal disease depending on traditional medical practice [23].

According to the World health organization (WHO), about $80 \%$ of the total population of the world mainly depends on traditional medicine and the use of plant extracts is mainly involved in the traditional treatment [24]. Natural substances serve as the reliable sources of most drugs and medicinal agents. From the ancient period of time, many plants are used as folk medicines to treat infectious diseases such as diarrhea, urinary tract infections, bronchitis, cutaneous abscesses and parasitic diseases [25]. Medicinal herbs constitute the major component of the traditional medicine practiced worldwide due to the economic viability, accessibility and ancestral experience [20]. Thus the interest and urgency of ethnobotanical research are essentially demandable [26]. Moreover, in practically, natural 
products have advantages over synthetic drug design in that it provides lead compounds having new structural features with novel biological activity. One-half of the medicines we use today has been derived from natural sources. In point of fact every pharmacological category of drugs includes a natural product prototype.

For these reasons, the present study was figured to identify phytoconstituents and evaluate the anti-inflammatory, anti-nociceptive and anti-diarrhoeal activities of methanol (MHAL) and ethyl acetate (EAHAL) extract of Hemigraphis alternata leaves.

\section{Materials and methods \\ Plant material}

The fresh leaves of Hemigraphis alternata were collected from Godkhali [The heaven of flowers] $\left(22.1678^{\circ} \mathrm{N}\right.$, $88.7881^{\circ}$ E), Jashore, Khulna, Bangladesh, in March 2018. The plant was botanically identified and confirmed by National Herbarium, Bangladesh.

\section{Extraction preparation}

Cold extraction was performed separately using $250 \mathrm{mg}$ and $300 \mathrm{mg}$ powdered leaves of Hemigraphis alternate by using Methanol and ethyl acetate as solvent. First, the leaves of Hemigraphis alternata were thoroughly washed 3-4 times successively with running water and once with sterile distilled water to remove all dirt, soil, and contaminants and dried in shade at room temperature $\left(25 \pm 2{ }^{\circ} \mathrm{C}\right)$ for two weeks and finally dried them for $24 \mathrm{~h}$ at $30 \pm 2{ }^{\circ} \mathrm{C}$ by using a laboratory dryer (memmert UN75, Germany) before to ground. The dried leaves were ground into coarse powder and passed through a 40-mesh size sieve to get fine powders. Powdered leaves (250 $\mathrm{mg}$ and $300 \mathrm{mg}$ ) were separately soaked in a sufficient amount of methanol $(1800 \mathrm{~mL})$ and ethyl acetate $(2000 \mathrm{~mL})$ in closed containers for 14 days at room temperature with periodical shaking and stirring. Separately, both mixtures were primarily filtered through fresh cotton and then through Whatman No.1 filters. Then extraction was completed by solvent evaporation with a rotary evaporator under reduced pressure at $40^{\circ} \mathrm{C}$ temperature and was yield semisolid crude extracts. The percentage yields of MHAL and EAHAL were $4.23 \%(w /$ w) and $1.95 \%(w / w)$, respectively. The extracts were then preserved in a refrigerator till further use.

\section{Phytochemical screening}

The start of the new millennium has signaled the initiation of a new era of drug discovery. Bioactive compounds deposited in medicinal plants can serve as important raw materials for pharmaceutical manufacturing.

Freshly prepared semisolid crude extracts (MHAL and EAHAL) were subjected to different qualitative tests according to Rahman and Billmary et al. [27, 28] to find out the presence of prominent phytoconstituents like carbohydrates, alkaloids, saponins, tannins, phenols, flavonoids, triterpenoids, glycosides, and fat \& fixed oils, through characteristic color changes.

\section{Molisch's test for carbohydrates}

For this test, around $500 \mathrm{mg}$ of crude extract was dissolved in $5 \mathrm{~mL}$ of distilled water and later filtered. After that, a few drops of Molisch's reagent ( $\alpha$-naphthol $10 \%(w / v)$ in $90 \%$ ethanol) were added to the filtrate. Then $1 \mathrm{~mL}$ of concentrated $\mathrm{H}_{2} \mathrm{SO}_{4}$ was poured carefully along the side of the test tube. Two minutes later, $5 \mathrm{~mL}$ of distilled water was added. A positive test, indicating the presence of carbohydrates, was confirmed with formation of dull violet or red color at the interphase of the two layers.

\section{Fehling's test for reducing sugars}

In Fehling test, $2 \mathrm{mg}$ plant extract was dissolved in $1 \mathrm{~mL}$ of distilled water and filtered. After that, $1 \mathrm{~mL}$ mixture of Fehling's solutions A and B (a ratio of 1:1) was added to the filtrate, which was heated in a water bath for a few minutes. Formation of brick-red precipitate confirmed the presence of reducing sugars.

\section{Mayer's test for alkaloids}

One or two drops of $0.35 \mathrm{~mol} / \mathrm{L}$ Mayer's reagent (potassium- mercuric iodide solution, $1.36 \mathrm{~g}$ mercuric chloride and $5 \mathrm{~g}$ of potassium iodide, dissolved in $100 \mathrm{~mL}$ distilled $\mathrm{H}_{2} \mathrm{O}$ ) was added to $2 \mathrm{~mL}$ ( $50 \mathrm{mg}$ extract dissolved in $5 \mathrm{~mL}$ of $1 \%$ aqueous $\mathrm{HCl}$ ) filtrate along the side of the test tube. A positive test, demonstrating the presence of alkaloids, was indicated by a white creamy precipitate.

\section{Frothing test for Saponins}

In frothing test, $100 \mathrm{mg}$ plant extract was dissolved in 10 $\mathrm{mL}$ of methanol for making stock solutions. These stock solutions were diluted to $0.5 \mathrm{mg} / \mathrm{mL}$ by the additions of $20 \mathrm{~mL}$ of distilled water. Test tube containing the dilution was then shaken for $15 \mathrm{~min}$. Formation of foam on the top of the test tubes indicated the presence of saponins.

\section{$\mathrm{FeCl}_{3}$ test for tannins}

$50 \mathrm{mg}$ crude extract was dissolved in $5 \mathrm{~mL}$ distilled water, followed by the addition of a few drops of $5 \%$ $\mathrm{FeCl}_{3}$. Tannin was confirmed by the development of a bluish- black color.

\section{Alkali test for flavonoids}

In alkali test, a few drops of $5 \% \mathrm{NaOH}$ solution were added to $1 \mathrm{~mL}$ of filtered stock solution $(100 \mathrm{mg}$ of extract dissolved in $10 \mathrm{~mL}$ of methanol), which produced a deep-yellow color. The color was lost in the presence of dilute $\mathrm{HCl}$ and confirmed flavonoids. 


\section{Salkowski's test for triterpenoids}

$2 \mathrm{mg}$ crude extract was shaken in $1 \mathrm{~mL}$ of $\mathrm{CHCl}_{3}$. Then, a few drops of concentrated $\mathrm{H}_{2} \mathrm{SO}_{4}$ were added to the solution along the side of the test tube. Development of a red-brown color at the interface indicated the presence of triterpenoids.

\section{Keller-killiani test for glycosides}

$1 \mathrm{ml}$ of extract, $1 \mathrm{ml}$ of Glacial acetic acid and few drops of $2 \% \mathrm{FeCl}_{3}$ were added and then $1 \mathrm{ml}$ of conc. $\mathrm{H}_{2} \mathrm{SO}_{4}$ is also added in the mixture. Appearance of Brown ring shows presence of glycosides.

\section{$\mathrm{CuSO}_{4}$ test for fat and fixed oils}

5 droops of extract solution $(0.25 \mathrm{~g}$ extract dissolved in $25 \mathrm{~mL}$ mother solvent) mixed with $1 \mathrm{~mL}$ of $1 \% \mathrm{CuSO}_{4}$ and then few drops of $10 \% \mathrm{NaOH}$ was added. Appearance of clean blue solution shows presence of fat and fixed oils.

\section{Experimental animals}

4-5 weeks aged one hundred and ninety male Swiss albino mice of body weight 20-30 g. (procured from Department of Pharmacy, Jahangirnagar University, Savar, Dhaka, Bangladesh) were used to run the anti-inflammatory, antinociceptive and antidiarrhoeal experiments. Before initiating the experiments, the animals were kept under standard environmental conditions, maintained 55\%-65\% relative humidity and exposed to alternative 12:12 $\mathrm{h}$ light and dark cycle at an ambient temperature of $26 \pm 2{ }^{\circ} \mathrm{C}$. Proper supply of foods and water ad libitum were ensured. Institutional Animal Ethical Committee of Jessore University of Science \& Technology, Jessore, Bangladesh was approved all protocols for the animal experimentation. Before the experiment, mice were accustomed for 10 days in our laboratory environment and ensured the constant environmental and adequate nutritional conditions throughout the period of the experiment.

\section{Acute toxicity study}

Adverse effects occurring from a single exposure or from multiple exposures over a short period of time (normally less than $24 \mathrm{~h}$ ) are regarded as acute toxicity [29]. Moreover, the acute toxicity study was performed according to the Organization of Economic Cooperation and Development (OECD) guidelines [30] for evaluating the half lethal dose $\left(\mathrm{LD}_{50}\right)$ of the experimental samples. Total fifteen mice were divided into three groups: control group (normal water) and test groups (MHAL and EAHAL) containing five mice in each group. Oral administration of the test samples (MHAL and EAHAL) at different concentrations $(100,250,500,1000,2000,3000$ and $4000 \mathrm{mg} / \mathrm{kg}$ body weight) were given to the test animals. After that the animals were noticed every $1 \mathrm{~h}$ for next $5-6 \mathrm{~h}$ for mortality, behavioral pattern changes such as weakness, aggressiveness, food or water refusal, diarrhea, salivation, convulsion, coma, injury, pain, discharge from eyes and ears, noisy breathing, changes in locomotor activity, or any signs of toxicity in each group of mice. In addition, at the end of a 2-week observation period, a final assessment of acute toxicity of each group of mice was also carried out [30].

\section{Drugs and chemicals}

Diclofenac sodium (DS) and Loperamide $\mathrm{HCl}$ were purchased from Square Pharmaceuticals Ltd. and ACME Laboratories Ltd., Bangladesh, respectively. All solvents and reagents used were of analytical grade and solvents obtained from Merck, Germany.

\section{Anti-inflammatory activity} Xylene-induced ear edema test

The model of Dai and Liu was followed to evaluate xylene-induced ear edema test in mice [31]. Consisting of five mice in each group, thirty mice were randomly divided into control group (distilled water, $10 \mathrm{~mL} / \mathrm{kg}$ body weight), positive control or standard group (Diclofenac sodium (DS), $100 \mathrm{mg} / \mathrm{kg}$ body weight), and test groups (MHAL and EAHAL at 200 and $400 \mathrm{mg} / \mathrm{kg}$ body weight). All mice had been fasted for $16 \mathrm{~h}$ with water ad libitum. Moreover, mice in the control group, positive control group, and test groups were treated with distilled water at a dose of $10 \mathrm{~mL} / \mathrm{kg}$, Diclofenac sodium at a dose of 100 $\mathrm{mg} / \mathrm{kg}$, as well as MHAL and EAHAL at doses of 200 and $400 \mathrm{mg} / \mathrm{kg}$ body weight respectively, orally. One hour after oral administration, $20 \mu \mathrm{L}$ of xylene was given to each mouse on the anterior and posterior surfaces of the right ear lobe, resulting induction of ear edema. Here, the untreated left ear was regarded as control. After $1 \mathrm{~h}$ of xylene application, mice were sacrificed by cutting off both ears with the utilization of $5 \mathrm{~mm}$ circular sections of the ears, then seized, and finally weighed. The weight of xylene-induced edema was calculated from the difference between the weight of ear treated with xylene (right ear) and the weight of ear left untreated (left ear).

The percentage inhibition of ear edema was calculated by the following formula.

Inhibition $(\%)=[1-\{$ Weight of edema (extract or standard drug)/ Weight of edema (normal control)\}] X 100.

\section{Cotton pellet-induced granuloma formation}

To evaluate the cotton pellet induced granuloma formation in mice, the method of Swingle and Shideman [32] was used with slight modification. Under light chloroform anesthesia and sterile technique, sterilized cotton pellets, weighing $(10 \pm 1) \mathrm{mg}$ of each pellet, were inserted subcutaneously, one on each side of the abdomen of the animal. Thirty mice were grouped and treated orally as mentioned before, once a day for 7 days. 
After continuous treatment, all mice were sacrificed on the 8th day. Granuloma wetted cotton pellets were removed and dried at $60^{\circ} \mathrm{C}$ for $24 \mathrm{~h}$ with a laboratory dryer. Then the dry cotton weight was recorded. The weight of granuloma formation was measured by the weight difference between the removed, dried cotton pellets, and the cotton pellets before insertion.

The percentage inhibition of granuloma formation was calculated by the following formula.

Inhibition $(\%)=[1-\{$ Weight of granuloma (extract or standard drug)/ Weight of granuloma (normal control)\}] X 100.

\section{Anti-nociceptive study}

\section{Formalin-induced paw licking}

To evaluate the analgesic activity of plant extracts, a slightly modified method of Hunskaar and Hole [33] was applied in formalin-induced paw licking test in mice. Containing five mice in each group, thirty healthy Swiss albino mice were divided into control group (distilled water, $10 \mathrm{~mL} / \mathrm{kg}$ body weight), positive control or standard group (Diclofenac sodium (DS), $100 \mathrm{mg} / \mathrm{kg}$ body weight), and test groups (MHAL and EAHAL at 200 and $400 \mathrm{mg} / \mathrm{kg}$ body weight). Mice were fasted for $16 \mathrm{~h}$ with water ad libitum prior to the experiment. Moreover, mice in the control group, positive control group, and test groups were treated with distilled water at a dose of $10 \mathrm{~mL} / \mathrm{kg}$, Diclofenac sodium at a dose of $100 \mathrm{mg} / \mathrm{kg}$, as well as MHAL and EAHAL at doses of 200 and $400 \mathrm{mg} /$ $\mathrm{kg}$ body weight respectively, orally. Each mouse was injected with 20 휠 $\mathrm{L}$ of $2.7 \%(\mathrm{v} / \mathrm{v})$ formalin solution into the dorsal surface of the left hind paw, $1 \mathrm{~h}$ after the respective treatment of each group. The time spent in licking, biting, and shaking behaviors was measured in seconds for $5 \mathrm{~min}$ after formalin injection, which was considered as the acute phase $(0-5 \mathrm{~min})$. Again, mice were monitored for $5 \mathrm{~min}$ after $20 \mathrm{~min}$ of injection which was defined as late phase (20-25 min).

The percentage of inhibition of licking was calculated by the following formula.

Inhibition $(\%)=[1-($ Licking time (standard or extracts) / Licking time (normal control)) $] \times 100$.

\section{Acetic acid-induced writhing test}

Analgesic activity was evaluated by the test of abdominal writhing induced by acetic acid in mice. This study was performed according to the method of Koster et al. [34]. Mice were fasted for $16 \mathrm{~h}$ with water ad libitum prior to the experiment. Mice were grouped and treated with extracts (MHAL and EAHAL) as mentioned before. Diclofenac sodium $(100 \mathrm{mg} / \mathrm{kg}$ body weight) was used as the standard or positive control and distilled water $(10 \mathrm{~mL} /$ $\mathrm{kg}$ body weight) as normal control. After forty-five minutes of respective treatment, each mouse was injected intraperitoneally with $0.7 \%(\mathrm{v} / \mathrm{v})$ acetic acid at a dose of $10 \mathrm{~mL} / \mathrm{kg}$ body weight. The writhing activity comprised of constriction of the abdominal muscles together with a stretching of the hind limbs. The number of writhing responses of each mouse was counted for a 5-min period, which began fifteen minutes late of acetic acid administration.

To calculate the percentage of inhibition of writhing, the following formula was used.

Inhibition $(\%)=[1-\{$ No. of writhing (standard or extracts) / No. of writhing (normal control)\}] $\times 100$.

\section{Antidiarrhoeal activity Castor oil induced antidiarrhoeal test}

A slightly modified method of Shoba and Thomas [35] was applied in castor oil induced antidiarrheal test in mice. It is one of the most acceptable methods to evaluate the antidiarrhoeal activity. By administering $0.5 \mathrm{~mL}$ of castor oil orally the preliminary screening of animals was performed, and those animals that started diarrhea were selected finally for the test. Thirty diarrheal screened mice were randomly divided into control group (distilled water, $10 \mathrm{~mL} / \mathrm{kg}$ body weight), positive control or standard group (Loperamide $\mathrm{HCl}, 3 \mathrm{mg} / \mathrm{kg}$ body weight), and test groups (MHAL and EAHAL at 200 and $400 \mathrm{mg} / \mathrm{kg}$ body weight), containing five mice in each group. Screened experimental animals were fasted for around $16 \mathrm{~h}$ with water ad libitum. Then mice in the control group, standard group, and test groups were treated with distilled water at a dose of 10 $\mathrm{mL} / \mathrm{kg}$, Loperamide $\mathrm{HCl}$ at a dose of $3 \mathrm{mg} / \mathrm{kg}$, as well as MHAL and EAHAL at doses of 200 and $400 \mathrm{mg} / \mathrm{kg}$ body weight respectively, orally. After $30 \mathrm{~min}$ of respective treatment, each animal received $0.5 \mathrm{~mL}$ of castor oil orally for initiating diarrhea. Observation for defecation continued up to $4 \mathrm{~h}$ on blotting paper lined individual cage was used for placing every animal. Blotting papers were replaced every hour. The number of diarrheal feces was count and recorded for a period of $4 \mathrm{~h}$.

The percentage of inhibition of defecation was calculated for every group of animals by the following formula.

Inhibition $(\%)=[1-\{$ Number of feces (extract or standard drug) / Number of feces (normal control)\}] X 100.

\section{Statistical analysis}

All results were expressed as mean \pm SEM (Standard Error of Mean). All data for statistical analyses of antiinflammatory, antinociceptive and antidiarrheal studies were analyzed by one-way ANOVA following Dunnett's test through the SPSS software (version 16; IBM Corporation, New York, USA). The obtained results were compared with the vehicle control group. The significance is presented at the level of $P<0.05$. 
Table 1 Phytochemical screening of MHAL and EAHAL

\begin{tabular}{llll}
\hline Phytoconstituents & Test name & \multicolumn{2}{l}{ Observation of various extracts } \\
\cline { 3 - 4 } & & MHAL & EAHAL \\
\hline Carbohydrates & Molisch's test & + & + \\
& Fehling's test & - & - \\
Alkaloids & Mayer's test & - & - \\
Saponins & Frothing test & - & + \\
Tannins & FeCl ${ }_{3}$ test & + & + \\
Flavonoids & Alkali test & + & - \\
Triterpenoids & Salkowski's test & + & + \\
Glycosides & Keller-killiani test & + & + \\
Fat \& Fixed oils & CuSO4 test & + & +
\end{tabular}

+ : presence of specific phytoconstituents; -: absence of specific phytoconstituents

\section{Results}

Phytochemical screening

It is important to delineate the chemical behavior of plant materials and also conducted in order to ascertain the liable phytoconstituents that offered biological activity. Phytochemical screening of the MHAL and EAHAL were showed the presence of several primary and secondary metabolites, or phytoconstituents, which are summarized in Table 1. In the phytochemical screening, MHAL and EAHAL were shown to have different compositions. EAHLA was showed the presence of saponins but it was not found in MHAL. On the other hand, flavonoids were present in MHAL but not in EAHAL. In addition, carbohydrate content in both extracts was indicated by Molisch's test, but not by Fehling's test.

\section{Acute toxicity}

In acute toxicity study behavioral changes or mortality or sign of toxicity were not observed during the 14-day observation period in mice receiving doses up to the high dose of $4000 \mathrm{mg} / \mathrm{kg}$ for MHAL as well as EAHAL or control group. No change was found in food intake or other behaviors during this observation period and was the same as prior to the experiment. So, this observation seemingly confirmed that the test groups did not experience acute oral toxicity at the given doses.

\section{Anti-inflammatory effect}

Xylene-induced ear edema test

In this study, the results of MHAL and EAHAL on xylene-induced ear edema in Swiss albino mice are documented in Table 2. The percentage of ear edema in mice was significantly reduced by administration of plant extracts and positive control. These findings proposed that both positive control (DS $100 \mathrm{mg} / \mathrm{kg}$ ) and extracts (MHAL and EAHAL) at both doses 200 and $400 \mathrm{mg} / \mathrm{kg}$ had significant (compared to control, $P<0.05$ ) inhibitory effect on the inflammation of ear edema in mice. The percentage inhibition of methanol and ethyl acetate extract of Hemigraphis alternata leaves at both doses was $20.12 \pm 7.81,34.10 \pm 8.10,32.68 \pm 4.90$ and $35.15 \pm$ $11.78 \%$ respectively in xylene induced edema test, and follows dose-dependent attitude. However, EAHAL 400 $\mathrm{mg} / \mathrm{kg}$ was found to be more effective $(35.15 \pm 11.78 \%)$ as an anti-inflammatory agent. Results are illustrated in Fig. 1.

\section{Cotton pellet-induced granuloma formation}

The effects of cotton pellet-induced granuloma formation of HMAL and EAHAL in mice are shown in Table 3. In this study, the methanol and ethyl acetate extracts were inhibited the granuloma formation by $19.17 \pm 14.08,32.43$ $\pm 10.65,25.43 \pm 10.96$ and $34.76 \pm 11.30 \%$ at the concentration of $200 \mathrm{mg} / \mathrm{kg}$ and $400 \mathrm{mg} / \mathrm{kg}$ respectively. All of the groups were showed significant percentage inhibition of granuloma formation and granuloma weight in mice (compared to control, $P<0.05$ ). Among all the extracts, EAHAL at the dose of $400 \mathrm{mg} / \mathrm{kg}$ was showed the highest percentage inhibition $(34.76 \pm 11.30 \%)$ of granuloma formation in mice, where positive control (DS $100 \mathrm{mg} / \mathrm{kg}$ ) was showed the apex percent inhibition $63.95 \pm 3.38 \%$. The obtained results are illustrated in Fig. 2.

\section{Anti-nociceptive effect \\ Formalin induced-paw licking}

The results of the anti-nociceptive activity of MHAL and EAHAL were measured by formalin induced-paw licking test that are displayed in Table 4. Formalin induced-paw licking is the biphasic pain response system. In the delayed

Table 2 Effect of standard and MHAL and EAHAL on Xylene induced ear edema test

\begin{tabular}{|c|c|c|c|c|}
\hline Treatment groups & Dose & Ear weight Differences (mg) & $\%$ of inhibition & $p$ value \\
\hline Control & $10 \mathrm{~mL} / \mathrm{kg}$ & $11.60 \pm 1.12$ & $0.00 \pm 0.00$ & - \\
\hline DS & $100 \mathrm{mg} / \mathrm{kg}$ & $5.60 \pm 0.93^{* * *}$ & $46.85 \pm 13.62^{* * *}$ & .000 \\
\hline MHAL & 200 mg/kg & $9.00 \pm 0.71$ & $20.12 \pm 7.81$ & .103 \\
\hline MHAL & $400 \mathrm{mg} / \mathrm{kg}$ & $7.40 \pm 0.75^{* *}$ & $34.10 \pm 8.10^{* *}$ & .008 \\
\hline EAHAL & $200 \mathrm{mg} / \mathrm{kg}$ & $8.17 \pm 0.98^{*}$ & $32.68 \pm 4.90^{*}$ & .023 \\
\hline EAHAL & 400 mg/kg & $6.75 \pm 0.85^{* *}$ & $35.15 \pm 11.78^{* *}$ & .004 \\
\hline
\end{tabular}

All of the experimental values are denoted as mean \pm SEM. MHAL $=$ Methanol extract of Hemigraphis alternata leaves. EAHAL $=$ Ethyl acetate extract of Hemigraphis alternata leaves. " ${ }^{* *}<0.05,^{* *}<0.01,^{* * *}<0.001$ versus control group (Dunnett's test)" 


\section{Xylene induced ear edema test}

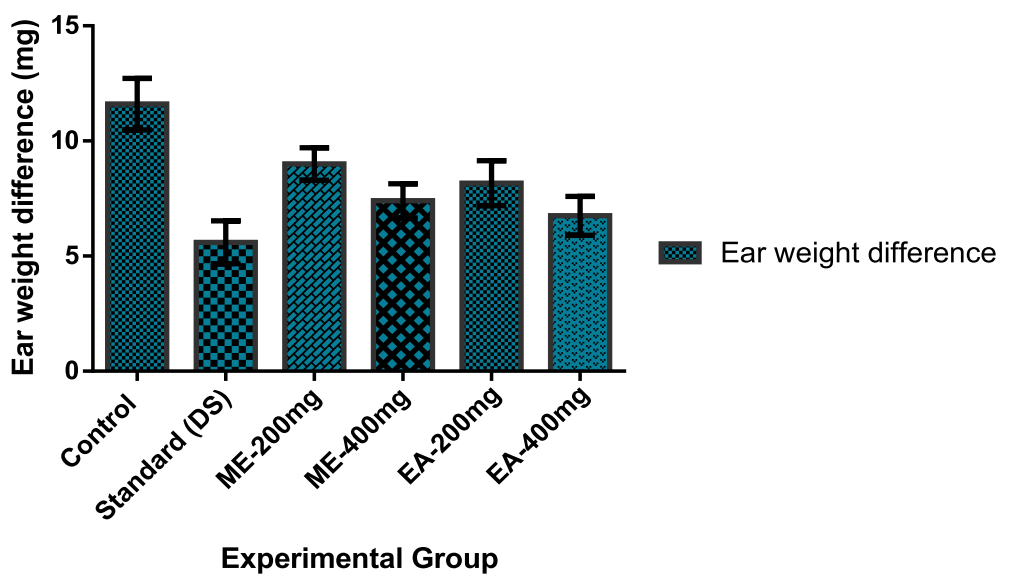

Fig. 1 Effect of Hemigraphis alternata methanolic and ethyl acetate extract treatment on xylene-induced ear edema in mice. Each bar represents the mean \pm standard error of the mean of ear edema weight of five animals

phase, the methanol and ethyl acetate extract of Hemigraphis alternata at the doses of 200 and $400 \mathrm{mg} / \mathrm{kg}$ were significantly $(P<0.05$, compared to control) inhibited paw licking on average by $81.54 \pm 4.45,88.12 \pm 1.33,83.14 \pm$ 3.93 and $88.21 \pm 2.23 \%$, respectively. Extracts were also showed significant inhibition $(P<0.05$, compared to control) in the acute phase. All effects were dose-dependent in manner, and formalin induced-paw licking results are illustrated in Fig. 3.

\section{Acetic acid-induced writhing test}

The effects of methanol and ethyl acetate extract of Hemigraphis alternata leaves on acetic acid-induced writhing in mice are shown in Table 5. Here, Diclofenac sodium was administered as the positive control and the inhibition of the acetic acid-induced writhing was observed as $74.15 \pm 4.86 \%$. Orally administered tested samples (MHAL and EAHAL) at the doses of 200 and 400 $\mathrm{mg} / \mathrm{kg}$ were expressed the notable effects (percent inhibition are $20.39 \pm 6.83,49.17 \pm 4.41, \quad 30.73 \pm 7.52$ and $54.00 \pm 2.38 \%$ respectively) in the writhing model in dose-dependent manner. Among all extracts, the highest percentage inhibition of writhing $(54.00 \pm 2.38 \%)$ was obtained by EAHAL at the dose of $400 \mathrm{mg} / \mathrm{kg}$. Figure 4 illustrated all results obtained from the acetic acid-induced writhing test.

\section{Antidiarrhoeal effect Castor oil-induced antidiarrhoeal test}

The results of antidiarrhoeal activity yield in castor oil-induced diarrhoeal model are enumerated in Table 6 . Both extracts (MHAL and EAHAL) at the doses of 200 $\mathrm{mg} / \mathrm{kg}$ and $400 \mathrm{mg} / \mathrm{kg}$ significantly $(P<0.05$, versus control) prolonged the time for induction of diarrhea and also decreased the frequency of defecation as well as the total number of wet feces in dose-dependent manner. Among the extracts (MHAL and EAHAL) Hemigraphis alternata leaves, the $400 \mathrm{mg} / \mathrm{kg}$ MHAL dose were showed the most promising effect $(P<0.01$, versus control and $67.73 \pm 5.77 \%$ inhibition) against castor oil induced diarrhea in mice. In this study, percent inhibitions by both extracts at both doses were $44.05 \pm 8.55,67.73 \pm$ $5.77,29.79 \pm 7.62$ and $51.19 \pm 7.81 \%$ respectively where Loperamide $\mathrm{HCl}$ exhibits $74.31 \pm 8.72 \%$ inhibition. In Fig. 5 results are illustrated.

Table 3 Effect of standard and MHAL and EAHAL on cotton pellet induced granuloma formation test

\begin{tabular}{|c|c|c|c|c|}
\hline Treatment groups & Dose & Granuloma weight (mg) & $\%$ of inhibition & $p$ value \\
\hline Control & $10 \mathrm{~mL} / \mathrm{kg}$ & $31.60 \pm 1.91$ & $0.00 \pm 0.00$ & - \\
\hline DS & 100 mg/kg & $11.60 \pm 1.69^{* * *}$ & $63.95 \pm 3.38^{* * *}$ & .000 \\
\hline MHAL & 200 mg/kg & $24.80 \pm 3.15$ & $19.17 \pm 14.08$ & .093 \\
\hline MHAL & 400 mg/kg & $20.60 \pm 2.16^{* *}$ & $32.43 \pm 10.65^{* *}$ & .006 \\
\hline EAHAL & 200 mg/kg & $23.33 \pm 2.47^{*}$ & $25.43 \pm 10.96^{*}$ & .032 \\
\hline EAHAL & 400 mg/kg & $19.25 \pm 2.29^{* *}$ & $34.76 \pm 11.30^{* *}$ & .004 \\
\hline
\end{tabular}

All of the experimental values are denoted as mean $\pm \mathrm{SEM} . \mathrm{MHAL}=$ Methanol extract of Hemigraphis alternata leaves. EAHAL $=$ Ethyl acetate extract of Hemigraphis

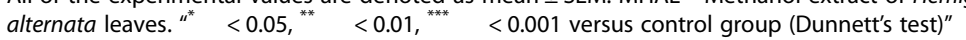




\section{Cotton pellet induced granuloma formation}

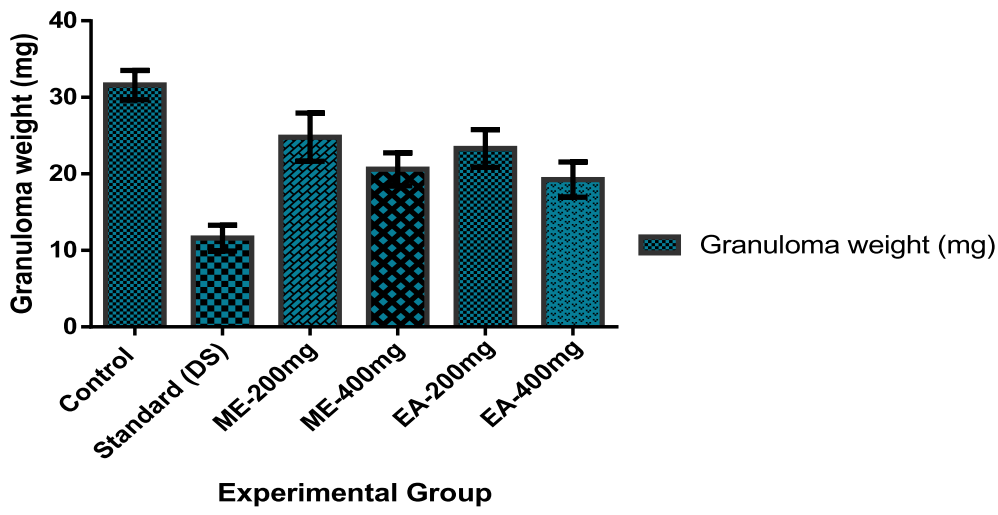

Fig. 2 Effect of Hemigraphis alternata methanolic and ethyl acetate extract treatment on dry granuloma weight after subcutaneous cotton pellet implantation. Difference between initial weight $(10 \pm 1 \mathrm{mg})$ and weight after overnight drying was considered to be the dry weight of the granuloma tissue. Each bar represents the mean \pm standard error of the mean of five animals

\section{Discussion}

In the ambivalent environment, plants may face biotic (injured by bacteria, fungi, virus, insects etc.) and abiotic (harmed by salinity, drought, sunlight, wind, deficiency of nutrients etc.) stress [36]. In this situation, they synthesize phytochemicals which have health influencing effect [37]. Generally, phytochemical components are identified as bioactive compounds of plant extracts and may be responsible for the diverse activities when herbs are used medicinally [2]. In the phytochemical analysis of Hemigraphis alternata leaves the presence of carbohydrates, tannins, flavonoids, glycosides, and triterpenoids were revealed which initiates drug discovery and development.

Since the beginning of human being development, many people used medicinal plants traditionally as a remedial purpose [38]. In case of investigation of therapeutic index of drugs and xenobiotics, the acute oral toxicity study is a vital factor [39]. Scientifically rigorous toxicity studies have been conducted on very few plant-derived products, although a suitable range of doses of the materials for successive usage can be obtained by these studies [40]. As no mortality was observed up to the dose as high as $4000 \mathrm{mg} / \mathrm{kg}$ in experimental condition, $\mathrm{LD}_{50}$ of Hemigraphis alternata leaves extract could not be obtained. The extract was found to be safe with a broad therapeutic range and two comparatively high doses $(200 \mathrm{mg} / \mathrm{kg}$ and $400 \mathrm{mg} / \mathrm{kg}$ ) for both MHAL and EAHAL were used for in-vivo doses.

We evaluated the anti-inflammatory activity of methanol and ethyl acetate extract of Hemigraphis alternata leaves by two established experimental methods. One is xylene-induced ear edema and another is cotton pellet-induced granuloma model. The presence of edema is one of the prime signs of inflammation [41] accompanied with intense vasodilation, edematous changes of skin and infiltration of inflammatory cells are noticed as remarkable signs of acute inflammation in xylene-induced ear edema test [42]. In this experiment, xylene-induced ear edema is associated by innate immunity response of the skin, a cytotoxicity reaction of activated T cells and then migration of PMN leucocytes which augment swelling and heaviness of the ear [43]. In case, ear edema is induced on account of released responsible inflammatory mediators such as bradykinin, histamine, and serotonin, as a result, vascular

Table 4 Effect of standard and MHAL and EAHAL in formalin-induced paw licking test

\begin{tabular}{|c|c|c|c|c|c|}
\hline \multirow[t]{2}{*}{ Group } & \multirow[t]{2}{*}{ Dose } & \multicolumn{2}{|l|}{ Acute Phase } & \multicolumn{2}{|l|}{ Late Phase } \\
\hline & & Licking time (s) & $\%$ inhibition & Licking time (s) & $\%$ inhibition \\
\hline Control & $10 \mathrm{~mL} / \mathrm{kg}$ & $133.20 \pm 6.48$ & $0.00 \pm 0.00$ & $55.57 \pm 6.35$ & $0.00 \pm 0.00$ \\
\hline DS & 100 mg/kg & $65.19 \pm 8.26^{*}$ & $51.73 \pm 4.01$ & $3.04 \pm 0.26^{*}$ & $93.99 \pm 1.24$ \\
\hline MHAL & 200 mg/kg & $69.83 \pm 8.29^{*}$ & $48.12 \pm 4.05$ & $9.77 \pm 2.06^{*}$ & $81.54 \pm 4.45$ \\
\hline MHAL & 400 mg/kg & $54.91 \pm 4.92^{*}$ & $58.77 \pm 3.39$ & $6.66 \pm 1.30^{*}$ & $88.21 \pm 1.33$ \\
\hline EAHAL & 200 mg/kg & $66.60 \pm 8.12^{*}$ & $50.47 \pm 4.19$ & $8.71 \pm 1.34^{*}$ & $83.14 \pm 3.93$ \\
\hline EAHAL & 400 mg/kg & $52.37 \pm 4.55^{*}$ & $60.63 \pm 3.13$ & $6.38 \pm 1.67^{*}$ & $88.12 \pm 2.23$ \\
\hline
\end{tabular}

Numbers of licking time inhibition are presented as (mean \pm standard error of mean). MHAL $=$ Methanol extract of Hemigraphis alternata leaves. EAHAL $=$ Ethyl acetate extract of Hemigraphis alternata leaves. ${ }^{*} \quad<0.05,0.01,0.001$ versus control group (Dunnett's test)" 


\section{Formalin-induced paw licking test}

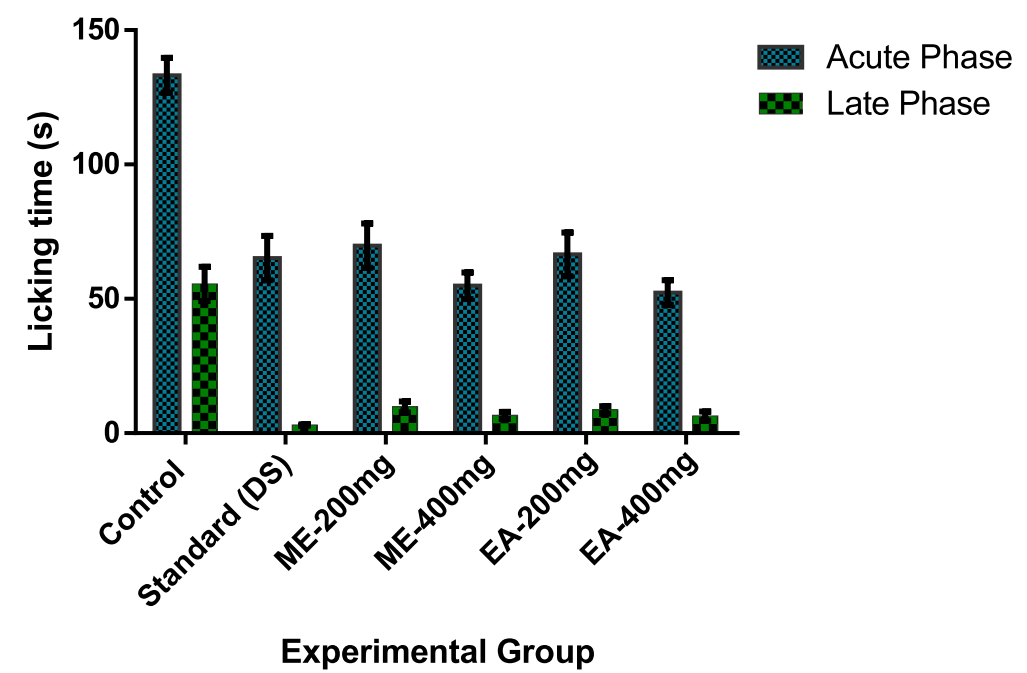

Fig. 3 Effect of Hemigraphis alternata methanolic and ethyl acetate extract treatment on formalin-induced paw licking in mice. Each bar represents the mean \pm standard error of the mean of paw licking time (s) of five animals

permeability and vasodilation are stimulated [44]. Results that showed the anti-inflammatory effects of all extracts (200 \& $400 \mathrm{mg} / \mathrm{kg}$ body weight) of MHAL and EAHAL in this model may be due to the suppression of phospholipase A2 which is associated in the pathophysiology of inflammation initiated by xylene. Moreover, wide ranges of phytoconstituents were responsible for anti-inflammatory activity includes alkaloids, glycosides, tannins, phenol, and triterpenoids etc. which are possessed in both extracts.

Cotton pellet-induced granuloma test is a widely used complex and well known durable process to assess the transudative, exudative and proliferative components of chronic inflammation [45]. It is used as an in vivo chronic inflammatory activity in the chronic phase of inflammation, which is characterized by monocyte infiltration, fibroblast proliferation, neutrophil infiltration, angiogenesis, and exudation [46]. The fluid greatly influences the wet weight of the granuloma absorbed by the pellet and the dry weight of the cotton pellet correlates well with the amount of granulomatous tissue formed [45]. In this study the MHAL and EAHAL significantly decreased the dry weight of the granuloma compared to control due to the ability of Hemigraphis alternata in reducing the number of fibroblasts, preventing angiogenesis and synthesis of collagen and mucopolysaccharide. Plant extract of MHAL and EAHAL probably suppress the T helper 1 (Th-1) T-lymphocyte pathway, which releases inflammatory cytokines such as interleukin-12 and interferon- $\alpha$ and controls cell-mediated immunity, may also be responsible for this anti-inflammatory action [47]. Statistical evaluation of the data confirmed that both doses of both extracts showed extremely significant anti-inflammatory activity with remarkable percent inhibition.

As an extensively reliable method, the formalin-induced paw licking model is widely used for investigating nociception as well as the possible mechanism of analgesia. The formalin-induced licking test constitutes two distinct mechanisms. The initial neurogenic pain (early

Table 5 Effect of standard and MHAL and EAHAL in acetic acid-induced writhing test

\begin{tabular}{|c|c|c|c|c|}
\hline Treatment groups & Dose & No. of writhing & $\%$ of inhibition & $p$ value \\
\hline Control & $10 \mathrm{~mL} / \mathrm{kg}$ & $37.60 \pm 2.16$ & $0.00 \pm 0.00$ & - \\
\hline DS & $100 \mathrm{mg} / \mathrm{kg}$ & $9.40 \pm 1.33^{* * *}$ & $74.15 \pm 4.86^{* * *}$ & .000 \\
\hline MHAL & $200 \mathrm{mg} / \mathrm{kg}$ & $29.60 \pm 2.09^{*}$ & $20.39 \pm 6.83^{*}$ & .041 \\
\hline MHAL & $400 \mathrm{mg} / \mathrm{kg}$ & $19.20 \pm 2.24^{* * *}$ & $49.17 \pm 4.41^{* * *}$ & .000 \\
\hline EAHAL & $200 \mathrm{mg} / \mathrm{kg}$ & $25.50 \pm 3.11^{* *}$ & $30.73 \pm 7.52^{* *}$ & .002 \\
\hline EAHAL & 400 mg/kg & $18.00 \pm 1.58^{* * *}$ & $54.00 \pm 2.38^{* * *}$ & .000 \\
\hline
\end{tabular}

All of the experimental values are denoted as mean \pm SEM. MHAL $=$ Methanol extract of Hemigraphis alternata leaves. EAHAL $=$ Ethyl acetate extract of Hemigraphis

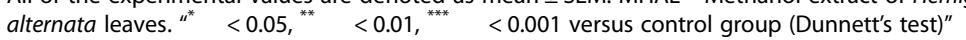




\section{Acetic acid-induced writhing test}

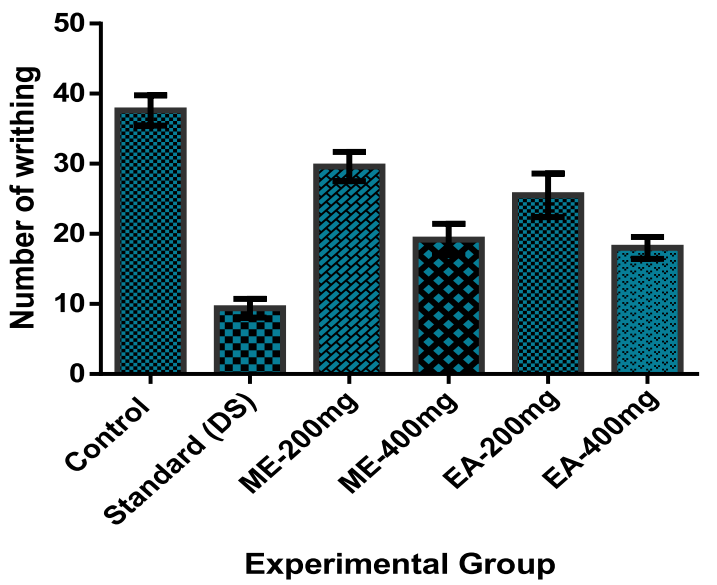

Fig. 4 Effect of Hemigraphis alternata methanolic and ethyl acetate extract treatment on acetic acid-induced writhing in mice. Each bar represents the mean \pm standard error of the mean of writhing of five animals

phase) arises within seconds of formalin injection and lasting during the first $5 \mathrm{~min}$. and the later inflammatory pain (late phase) lasting from 15 to $30 \mathrm{~min}$. After injection of formalin [33]. The early phase exhibits the direct results of chemically stimulation of peripherally localized TRPA-1 containing nociceptors and a consequent C-fibre activation and can be mainly suppressed by centrally acting analgesics. The late phase seems to be dependent on the combination of an inflammatory pain which arises from the spinal neuro-hyperactivity reaction in the peripheral tissue and function changes in the dorsal horn of the spinal cord, which seems to be initiated by $\mathrm{C}$-fibre barrage $[48,49]$. Centrally acting drugs show the gracious response in both phases (acute and delayed phase) whereas peripherally acting drugs act only in the late phase [50]. In this study, both doses (200 and 400 $\mathrm{mg} / \mathrm{kg}$ ) of MHAL and EAHAL were worked on both acute and late phase and showed antinociceptive activity by inhibiting inflammatory mediators.

Peripheral analgesic activity can also be evaluated by acetic acid induced writhing method. The broadly acetic acid-induced writhing test is being primarily used for the appraisement of antinociceptive activity of natural composites. In writhing response experiments, the analgesic mechanism has been characterized as the release of different endogenous noxious mediators such as bradykinin, serotonin, histamine, and substance P [21, 51]. The intraperitoneally injection of acetic acid produced nociception in the form of contraction of the abdominal muscle accompanied by an extension of the forelimbs and body elongation [52]. In order to interpret possible mechanism of acetic acid-induced writhing in mice; as different mechanism may be smeared in the release of biogenic amines, reduction of muscular constriction for instance, cyclooxygenases and their metabolites inhibition and through opioids receptors mechanisms [53]. In this study, MHAL and EAHAL at both doses of 200 and $400 \mathrm{mg} / \mathrm{kg}$ were showed significant inhibition of acetic acid-induced writhing and this might occur due to the inhibition of endogenous mediators or blockage of prostaglandin pathways. Further study is necessary to make final conclusion.

Castor oil-induced diarrhoeal model is well figured to evaluate the antidiarrhoeal activity of plant extract in

Table 6 Effect of standard and MHAL and EAHAL in Castor oil induced diarrhoeal model

\begin{tabular}{lllll}
\hline Treatment groups & Dose & No. of diarrhoeal feces & \% of inhibition & $p$ value \\
\hline Control & $10 \mathrm{~mL} / \mathrm{kg}$ & $9.00 \pm 1.58$ & $0.00 \pm 0.00$ & - \\
Loperamide $\mathrm{HCl}$ & $3 \mathrm{mg} / \mathrm{kg}$ & $2.20 \pm 0.73^{* * *}$ & $74.31 \pm 8.72^{* * *}$ & $44.05 \pm 8.55^{*}$ \\
MHAL & $200 \mathrm{mg} / \mathrm{kg}$ & $5.20 \pm 1.39^{*}$ & $67.73 \pm 5.77^{* *}$ & .046 \\
MHAL & $400 \mathrm{mg} / \mathrm{kg}$ & $3.20 \pm 1.07^{* *}$ & $29.79 \pm 7.62$ & .003 \\
EAHAL & $200 \mathrm{mg} / \mathrm{kg}$ & $6.67 \pm 0.80$ & $51.19 \pm 7.81^{* *}$ & .212 \\
EAHAL & $400 \mathrm{mg} / \mathrm{kg}$ & $3.75 \pm 0.85^{* *}$ & .010 \\
\hline
\end{tabular}

All of the experimental values are denoted as mean \pm SEM. MHAL $=$ Methanol extract of Hemigraphis alternata leaves. EAHAL $=$ Ethyl acetate extract of Hemigraphis

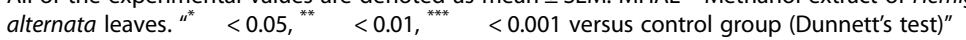




\section{Castor oil induced diarrhoeal test}

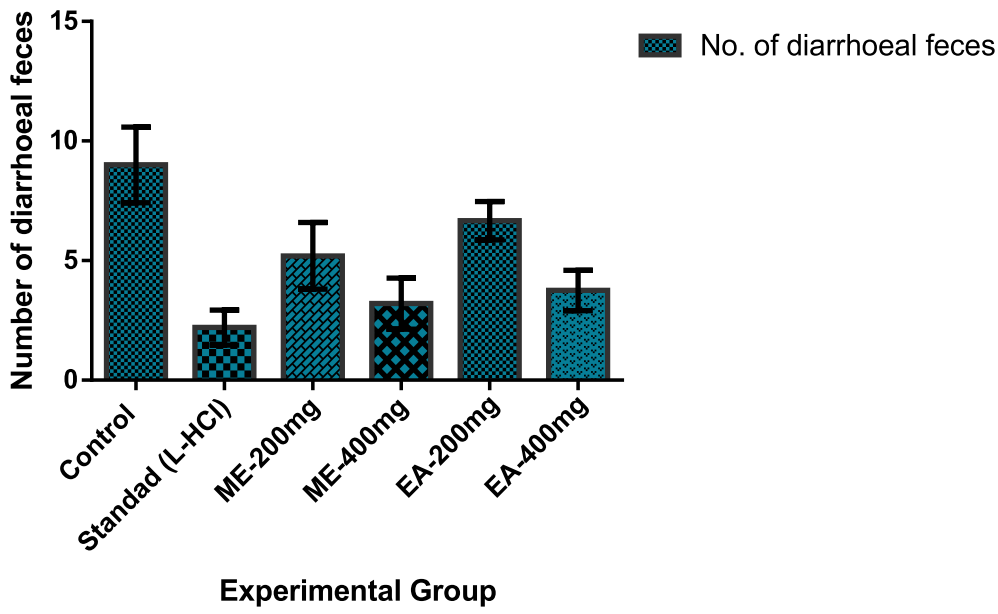

Fig. 5 Effect of Hemigraphis alternata methanolic and ethyl acetate extract treatment on castor oil induced diarrhea in mice. Each bar represents the mean \pm standard error of the mean of diarrhoeal feces of five animals

experimental animals. The effluence of ricinoleic acid, the main active ingredient of castor oil results in irritation and inflammation of the intestinal mucosa, responsible for the release of prostaglandins, which stimulates motility and secretion [54]. In addition, it is also reported to reduce active $\mathrm{Na}+$ and $\mathrm{K}+$ absorption and decrease $\mathrm{Na}+\mathrm{K}+$ ATPase activity in the small intestine and colon [55]. Above results enhance the peristaltic activity and produce permeability changes in the intestinal mucosal membrane to electrolytes and water markedly reduced the intestinal transit in mice $[56,57]$. Extracts of MHAL and EAHAL at a dose of $200 \mathrm{mg} / \mathrm{kg}$ and 400 $\mathrm{mg} / \mathrm{kg}$ may exhibit the antidiarrhoeal activity due to the inhibition of electrolyte permeability of the intestine and prostaglandin release. It might be assumed that the antidiarrheal action of plant extract was exerted by the antisecretory mechanism. Therefore, considering the potential bioactivity, the plant materials can be further studied extensively to find out their unexplored efficacy and to rationalize their uses as traditional medicines.

\section{Conclusions}

Existing results of this study confirmed that the methanol and ethyl acetate extracts of Hemigraphis alternate leaves were showed significant anti-inflammatory, antinociceptive, and antidiarrhoeal activities that support this plant for the treatment of traditional medicine. Of which the anti-inflammatory and analgesic activity of crude extracts were highly significant. We hope that the further detailed investigation is underway to determine the exact bioactive phytoconstituents that are responsible for those activities of this plant as traditional medicine and acclaimed effectiveness in treating several painful, inflammatory, and diarrhoeal conditions especially tissue injuries. Moreover, it could be a potential source for novel 'lead' discovery for anti-inflammatory, antinociceptive and antidiarrhoeal drug development.

Abbreviations

DS: Diclofenac Sodium; LD 50 : Lethal Dose; NSAIDs: Non-steroidal antiinflammatory drugs; OECD: Organisation for Economic Co-operation and Development; p.o.: Orally; TRPA1: Transient receptor potential ankyrin 1

\section{Acknowledgements}

I would like to thank Md. Abdullah Aziz and Md. Jashim Uddin, Assistant Professor, Department of Pharmacy, Jessore University of Science and Technology (JUST), Jessore, Bangladesh for giving valuable ideas during experimental periods. Authors are also grateful to the authority of the Department of Pharmacy, JUST for giving the opportunity to conduct such valuable experiments and providing necessary chemicals, instruments and utility support.

\section{Conflict of interest}

The authors declare that there is no conflict of interests regarding the publication of this paper.

\section{Funding}

There hadn't any funding supports for carrying this research. The total cost of completing the research work was carried by authors own finance.

Availability of data and materials

Not applicable.

Authors' contributions

SMMR and MI carried out the collection of plant, extraction process and conducted the research work. SMMR wrote the manuscript. AH and MNI carried out conception and design of the study, statistical analysis and interpretation of data. FM and SMMR helped in the plant collection procedure and conducted the research work. BS, MSI and MHR revised the manuscript and guided to improve the quality of final manuscript. All authors read and approved the final manuscript.

\section{Ethics approval and consent to participate}

This study was approved by ethical research committee of Jashore University of Science and Technology, Jashore- 7408, Bangladesh.

Consent for publication

Not applicable. 


\section{Publisher's Note}

Springer Nature remains neutral with regard to jurisdictional claims in published maps and institutional affiliations.

\section{Author details}

'Department of Pharmacy, Faculty of Biological Science and Technology, Jashore University of Science and Technology, Jashore 7408, Bangladesh. ${ }^{2}$ Department of Genetic Engineering and Biotechnology, Jashore University of Science and Technology, Jashore 7408, Bangladesh.

Received: 23 October 2018 Accepted: 6 March 2019 Published online: 02 April 2019

\section{References}

1. Jain NK, Kulkarni SK, Singh A. Modulation of NSAID-induced antinociceptive and anti-inflammatory effects by a2-adrenoceptor agonists with gastroprotective effects. Life Sci. 2002;70(24):2857-69.

2. Alabri TH, Al Musalami AH, Hossain MA, Weli AM, Al-Riyami Q. Comparative study of phytochemical screening, antioxidant and antimicrobial capacities of fresh and dry leaves crude plant extracts of Datura metel L. Journal of King Saud University-Science. 2014;26(3):237-43.

3. Saravanan J, Shariff WR, Joshi NH, Varatharajan R, Joshi VG, Karigar AA Preliminary Pharmacognostical and phytochemical studies of leaves of Hemigraphis colorata. Research Journal of Pharmacognosy and Phytochemistry. 2010;2(1):15-7.

4. Anitha VT, Marimuthu J, Jeeva S. Anti-bacterial studies on Hemigraphis colorata (Blume) HG Hallier and Elephantopus scaber L. Asian Pac J Trop Med. 2012;5(1):52-7.

5. Sheu JR, Jayakumar T, Chang CC, Chen YC, Priya S, Ong ET, Chiou HC, Elizebeth AR. Pharmacological actions of an Ethanolic extracts of the leaves Hemigraphis colorata and Clerodendron phlomoides. Clinical Mol Med. 2012; 3(1):1-3.

6. Silja VP, Varma KS, Mohanan KV. Ethnomedicinal plant knowledge of the Mullu kuruma tribe of Wayanad district. Kerala. .

7. Bourdy G, Walter A. Maternity and medicinal plants in Vanuatu I. The cycle of reproduction. J Ethnopharmacol. 1992;37(3):179-96.

8. Gayathri V, Lekshmi P, Padmanabhan RN. Antidiabetes and hypoglycaemic properties of Hemigraphis colorata in rats. International J Pharam Science. 2011:4(2):224-328.

9. Barton GM. A calculated response: control of inflammation by the innate immune system. J Clin Invest. 2008;118(2):413-20.

10. Ferrero-Miliani $L$, Nielsen $\mathrm{OH}$, Andersen PS, Girardin SE. Chronic inflammation: importance of NOD2 and NALP3 in interleukin-1 $\beta$ generation. Clinical \& Experimental Immunology. 2007;147(2):227-35.

11. Karin M, Lawrence T, Nizet V. Innate immunity gone awry: linking microbial infections to chronic inflammation and cancer. Cell. 2006;124(4):823-35.

12. Dassoler M, Schwanz M, Busseto F, Moreira EA, Gutierrez L. Perfil fitoquímico e ensaio farmacológico de Averrhoa carambola L.(Oxalidaceae). J Brasileiro Fitomedicina. 2004;2:4-8

13. Breivik H, Collett B, Ventafridda V, Cohen R, Gallacher D. Survey of chronic pain in Europe: prevalence, impact on daily life, and treatment. Eur J Pain. 2006;10(4):287-333.

14. Wang Q, Kuang H, Su Y, Sun Y, Feng J, Guo R, Chan K. Naturally derived anti-inflammatory compounds from Chinese medicinal plants. J Ethnopharmacol. 2013;146(1):9-39.

15. Uddin MJ, Rahman MM, Abdullah-Al-Mamun M, Sadik G. Vanda roxburghii: an experimental evaluation of antinociceptive properties of a traditional epiphytic medicinal orchid in animal models. BMC Complement Altern Med. 2015;15(1):305.

16. Ingrasciotta Y, Sultana J, Giorgianni F, Fontana A, Santangelo A, Tari DU, Santoro D, Arcoraci V, Perrotta M, Ibanez L, Trifirò G. Association of individual non-steroidal anti-inflammatory drugs and chronic kidney disease: a population-based case control study. PLoS One. 2015;10(4):e0122899.

17. Wallace JL. Pathogenesis of NSAID-induced gastroduodenal mucosal injury. Bailliere's Best Practice and Research in Clinical Gastroenterology. 2001;15(5): 691-704.

18. Moritz A. The dangerous side effects of steroids, arthritis drugs, and NSAIDs, 'Ener-chi wellness center; 2011.

19. Ricardo Buenaventura M, Rajive Adlaka M, Nalini SM. Opioid complications and side effects. Pain physician. 2008;11:S105-20.
20. Wendel GH, Maria AO, Guzmán JA, Giordano O, Pelzer LE. Antidiarrheal activity of dehydroleucodine isolated from Artemisia douglasiana. Fitoterapia. 2008;79(1):1-5.

21. Muhammad N, Saeed M, Khan H. Antipyretic, analgesic and antiinflammatory activity of Viola betonicifolia whole plant. BMC Complement Altern Med. 2012;12(1):59.

22. Viswanatha GL, Hanumanthappa S, Krishnadas N, Rangappa S. Antidiarrheal effect of fractions from stem bark of Thespesia populnea in rodents: possible antimotility and antisecretory mechanisms. Asian Pac J Trop Med. 2011;4(6):451-6.

23. Jebunnessa US, Mahabub-Uz-Zaman M, Akter R, Ahmed NU. Antidiarrheal activity of ethanolic bark extract of Mitragyna diversifolia. Bangladesh J Pharmacol. 2009:4:144-6.

24. Beverly CD, Sudarsanam G. Ethnomedicinal plant knowledge and practice of people of Javadhu hills in Tamilnadu. Asian Pac J Trop Biomed. 2011;1(1): 79-81.

25. Hossain S, Kader G, Nikkon F, Yeasmin T. Cytotoxicity of the rhizome of medicinal plants. Asian Pac J Trop Biomed. 2012;2(2):125.

26. Hammond JA, Fielding D, Bishop SC. Prospects for plant anthelmintics in tropical veterinary medicine. Vet Res Commun. 1997;21(3):213-28.

27. Rahman SMM, Sajon SR, Ahamed A, Islam A, Islam MS, Hossain MI. Phytochemical screening and evaluation of antidiarrhoeal activity of Ficus hispida leaves. Int J Pharmacognosy. 2018;5(8):493-9.

28. Billmary C, Janne R, Lucero M, Maria C. Preliminary phytochemical screening of Pimenta racemosa var. racemosa (Myrtaceae) from Táchira-Venezuela. Pharmacologyonline. 2014;2:61-8.

29. Walum E. Acute oral toxicity. Environ Health Perspect. 1998;106(Suppl 2):497

30. Organization for Economic Co-operation and Development/Organisation de Cooperation et de Developpement Economiques. OECD/OCDE; 423, 2001.

31. Yue $D$, Lianhua $L$, Junping K. Anti-inflammatory effect of aqueous extract of Wu-HU-tang. Journal of China Pharmaceutical University. 1995;06.

32. Swingle KF, Shideman FE. Phases of the inflammatory response to subcutaneous implantation of a cotton pellet and their modification by certain antiinflammatory agents. J Pharmacol Exp Ther. 1972;183(1):226-34.

33. Hunskaar S, Hole K. The formalin test in mice: dissociation between inflammatory and non-inflammatory pain. Pain. 1987;30(1):103-14.

34. Koster R, Anderson M, De-Beer EJ. Acetic acid analgesic screening. Fed Proc. 1959;18:412-7.

35. Shoba FG, Thomas M. Study of antidiarrhoeal activity of four medicinal plants in castor-oil induced diarrhoea. J Ethnopharmacol. 2001;76(1):73-6.

36. Flynn P. Biotic vs. abiotic - distinguishing disease problems from environmental stresses. ISU Entomology. 2003.

37. Singh S. Enhancing phytochemical levels, enzymatic and antioxidant activity of spinach leaves by chitosan treatment and an insight into the metabolic pathway using DART-MS technique. Food Chem. 2016;199:176-84.

38. Uddin G, Rauf A, Siddiqui BS, Shah SQ. Preliminary comparative phytochemical screening of Diospyros lotus Stewart. Middle-East J Sci Res. 2011;10(1):78-81.

39. Sahni C, Shakil NA, Jha V, Gupta RK. Screening of nutritional, phytochemical, antioxidant and antibacterial activity of the roots of Borassus flabellifer (Asian Palmyra palm). Journal of Pharmacognosy and Phytochemistry. 2014; $1: 3(4)$

40. Jothy SL, Zakaria Z, Chen Y, Lau YL, Latha LY, Sasidharan S. Acute oral toxicity of methanolic seed extract of Cassia fistula in mice. Molecules. 2011; 16(6):5268-82.

41. Sur TK, Pandit S, Battacharyya D, Kumar CA, Lakshmi SM, Chatttopadhyay D, Mandal SC. Studies on the antiinflammatory activity of Betula alnoides bark. Phytotherapy Research: An International Journal Devoted to Pharmacological and Toxicological Evaluation of Natural Product Derivatives. 2002;16(7):669-71.

42. Igbe I, Ching FP, Eromon A. Anti-inflammatory activity of aqueous fruit pulp extract of Hunteria umbellata K. Schum in acute and chronic inflammation. Acta Pol Pharm Drug Res. 2010;67:81-5

43. Kodithuwakku ND, Pan M, Zhu YL, Zhang YY, Feng YD, Fang WR, Li YM. Anti-inflammatory and antinociceptive effects of Chinese medicine SQ gout capsules and its modulation of pro-inflammatory cytokines focusing on gout arthritis. J Ethnopharmacol. 2013;150(3):1071-9.

44. Sokeng SD, Koubé J, Dongmo F, Sonnhaffouo S, Nkono BL, Taïwé GS, Cherrah Y, Kamtchouing P. Acute and chronic anti-inflammatory effects of the aqueous extract of Acacia nilotica (L.) Del. (Fabaceae) pods. Academia Journal of Medicinal Plants. 2013;1(1):1-5. 
45. Babu NP, Pandikumar P, Ignacimuthu S. Anti-inflammatory activity of Albizia lebbeck Benth., an ethnomedicinal plant, in acute and chronic animal models of inflammation. J Ethnopharmacol. 2009;125(2):356-60.

46. Majno G. Chronic inflammation: links with angiogenesis and wound healing. Am J Pathol. 1998;153(4):1035.

47. Yadav SS, Galib PK, Ashok BK, Ravishankar B. Evaluation of immunomodulatory activity of "Shirish avaleha"-an Ayurvedic compound formulation in albino rats. Journal of Ayurveda and integrative medicine. 2011 Oct;2(4):192.

48. Khan $\mathrm{H}$, Khan MA, Hussain S, Gaffar R, Ashraf N. In vivo antinociceptive and anticonvulsant activity of extracts of Heliotropium strigosum. Toxicol Ind Health. 2016;32(5):860-5.

49. Mino J, Acevedo C, Moscatelli V, Ferraro G, Hnatyszyn O. Antinociceptive effect of the aqueous extract of Balbisia calycina. J Ethnopharmacol. 2002; 79(2):179-82.

50. Azadmehr A, Sofiabadi M, Hajiaghaee R. Analgesic effect and immunomodulation response on pro-inflammatory cytokines production by Scrophularia megalantha extract. Trop J Pharm Res. 2013;12(6):935-9.

51. Ahmed S, Sultana M, Hasan MM, Azhar I. Analgesic and antiemetic activity of Cleome viscosa L. Pak J Bot. 2011;43(Special issue):119-22.

52. Rauf A, Khan R, Khan H, Ullah B, Pervez S. Antipyretic and antinociceptive potential of extract/fractions of Potentilla evestita and its isolated compound, acacetin. BMC Complement Altern Med. 2014;14(1):448.

53. Hasnain $F$, Janbaz KH, Qureshi MA. Analgesic effect of ketamine and morphine after tonsillectomy in children. Pak J Pharm Sci. 2012;25(3).

54. Pierce NF, Carpenter CC, Elliott HL, Greenough WB. Effects of prostaglandins, theophylline, and cholera exotoxin upon transmucosal water and electrolyte movement in the canine jejunum. Gastroenterology. 1971;60(1):22-32

55. Tenório JA, Dulciana S, da Silva TM, da Silva TG, Ramos CS. Solanum paniculatum root extract reduces diarrhea in rats. Rev Bras. 2016;26(3):375-8.

56. Capasso FN, Mascolo N, Autore G, Romano V. Laxatives and the production of autacoids by rat colon. J Pharm Pharmacol. 1986;38(8):627-9.

57. Abdullahi AL, Agho MO, Amos S, Gamaniel KS, Wambebe C. Antidiarrhoeal activity of the aqueous extract of Terminalia avicennoides roots. Phytother Res. 2001:15(5):431-4.

\section{Submit your manuscript to a SpringerOpen ${ }^{\circ}$ journal and benefit from:}

- Convenient online submission

- Rigorous peer review

- Open access: articles freely available online

- High visibility within the field

- Retaining the copyright to your article

Submit your next manuscript at $\boldsymbol{\nabla}$ springeropen.com 